\title{
Between Gospel and Election
}

\section{Explorations in the Interpretation of Romans 9-11 Ed. by Florian Wilk and J. Ross Wagner with the assistance of Frank Schleritt}

[Zwischen Evangelium und Erwählung. Untersuchungen zur Auslegung von Römer 9-11.]

Veröffentlicht auf Englisch.

Wie verhält sich der Wahrheitsanspruch der Christusbotschaft zum biblischen Zeugnis von der Erwählung des jüdischen Volkes? In Römer 9-11 ist Paulus tief in diese theologische Grundfrage eingedrungen. Die Interpretation der Kapitel ist indes seit langem umstritten. Der vorliegende Band wertet den gegenwärtigen Forschungsstand aus und entwickelt im Spannungsfeld zwischen der »New Perspective on Paul« und dem christlich-jüdischen Gespräch neue Ansätze für die Auslegung. 26 englisch- und deutschsprachige Beiträge aus den Bereichen Bibelwissenschaft, Judaistik, Systematische Theologie und Praktische Theologie untersuchen die theologie- und auslegungsgeschichtlichen Horizonte, die literarischen Kontexte, den Argumentationsgang, den theologischen Gehalt und die Gegenwartsbedeutung der paulinischen Darlegungen.

J.ROSS WAGNER

with the assistance of

with the assistance of
FRANK SCHLERITT

Inhaltsübersicht

Berndt Schaller: Die Rolle des Paulus im Verhältnis zwischen Christen und Juden - N. Thomas Wright: Romans 9-11 and the »New Perspective« - Klaus Haacker: Das Thema von Römer 9-11 als Problem der Auslegungsgeschichte - Mark Reasoner: Romans 9-11 Moves from Margin to Center, from Rejection to Salvation: Four Grids for Recent English-Language Exegesis John M. G. Barclay: Unnerving Grace: Approaching Romans 9-11 from The Wisdom of Solomon - Annette Steudel: Die Texte aus Qumran als Horizont für Römer 9-11. Israel-Theologie, Geschichtsbetrachtung, Schriftauslegung - Dieter Sänger: »Er wird die Gottlosigkeit von Jakob entfernen« (Röm 11,26). Kontinuität und Wandel in den Israelaussagen des Apostels Paulus Susan Eastman: Israel and Divine Mercy in Galatians and Romans - William S. Campbell: The Addressees of Paul's Letter to the Romans: Assemblies of God in House Churches and Synagogues? - Christoph Stenschke: Römer 9-11 als Teil des Römerbriefs - Florian Wilk: Rahmen und Aufbau von Römer 9-11 - Beverly Roberts Gaventa: On the Calling-Into-Being of Israel: Romans 9:6-29 - Frank Schleritt: Das Gesetz der Gerechtigkeit. Zur Auslegung von Römer 9,30-33 - Friedrich Avemarie: Israels rätselhafter Ungehorsam. Römer 10 als Anatomie eines von Gott provozierten Unglaubens - Enno Edzard Popkes: »Und David spricht ...« Zur Rezeption von Ps LXX 68,23 f. im Kontext von Röm 11,1-10 - Mark D. Nanos: »Broken Branches«: A Pauline Metaphor Gone Awry? (Romans 11:11-24) - Reinhard Feldmeier: Vater und Töpfer? Zur Identität Gottes im Römerbrief - A. Katherine Grieb: Paul's Theological Preoccupation in Romans 9-11 - Wolfgang Reinbold: Zur Bedeutung des Begriffes »Israel« in Römer 9-11 - J. Ross Wagner: »Not from the Jews Only, But Also from the Gentiles«: Mercy to the Nations in Romans 9-11 - Karl-Wilhelm Niebuhr: »Nicht alle aus Israel sind Israel« (Röm 9,6b). Römer 9-11 als Zeugnis paulinischer Anthropologie - Notger Slenczka: Römer 9-11 und die Frage nach der Identität Israels - Katherine Sonderegger: The Doctrine of Election in Romans 9-11 - Martin Rothgangel: Christliche Identität ohne antijüdische Kontrastfolie. Zur Bildungsrelevanz von Römer 9-11 - R. Kendall Soulen: »They are Israelites«: The Priority of the Present Tense for JewishChristian Relations - Wolfgang Kraus: Die Bedeutung von Römer 9-11 im christlich-jüdischen Gespräch

Frank Schleritt Keine aktuellen Daten verfügbar.

J. Ross Wagner Born 1966; 1998 PhD from Duke University; since 2013 Associate Professor of New Testament at Duke University.

Florian Wilk Geboren 1961; 1981-88 Studium der Ev. Theologie in Göttingen und St. Andrews; 1996 Promotion und 2001 Habilitation an der Theologischen Fakultät der Friedrich-Schiller-Universität Jena; seit 2003 Professor für Neues Testament an der Theologischen Fakultät der Georg-August-Universität Göttingen.

Jetzt bestellen:

https://mohrsiebeck.com/buch/between-gospel-and-election-9783161515460?no_cache=1

order@mohrsiebeck.com

Telefon: +49 (0)7071-923-17

Telefax: $+49(0) 7071-51104$ 